\title{
FAKTOR-FAKTOR YANG MEMPENGARUHI JUMLAH DEPOSITO MUDHARABAH BANK SYARIAH DI INDONESIA (Periode Tahun 2013-2016) ${ }^{1}$
}

\author{
Rosi Astrika Agustina \\ Mahasiswa Progam Studi S1 Ekonomi Islam - Fakultas ekonomi dan Bisnis - Universitas \\ Airlangga \\ Email: rosi.astrika-12@feb.unair.ac.id \\ Dina Fitrisia Septiarini \\ Departemen Ekonomi Syariah - Fakultas Ekonomi dan Bisnis - Universitas Airlangga \\ Email: dina.fitrisia@feb.unair.ac.id
}

\begin{abstract}
:
The aim of the study was to determine influence inflation, profit sharing level and corporation size to mudharabah deposit amount of Islamic banks in Indonesia year of period 2013-2016. This study used quantitative approach. The data used for this study are quarterly data gathered from per quarterly financial report of Islamic banks in Indonesia period 20132016.

Dependent variable in the study is profit sharing level and corporation size, then independent variable are inflation. This research used analisys technical panel data regression. The regression result of this study indicate that variable that the inflation and the size of the company a significant effect on the mudharabah deposit amount. While, variable that the variable level revenue sharing significant effect on the amount of mudharabah deposit Islamic bank in Indonesia
\end{abstract}

\section{Keywords: Mudharabah Deposit, Inflation, Profit Sharing Level, Corporation Size}

\section{PENDAHULUAN}

Ekonomi Islam bertujuan untuk mewujudkan tingkat pertumbuhan ekonomi jangka panjang dan memaksimalkan kesejahteraan manusia. Kesejahteraan yang dimaksud adalah terpenuhinya kebutuhan individu masyarakat dengan memperhatikan keseimbangan makro ekonomi, keseimbangan ekologi dan tetap memperhatikan nilai-nilai keluarga dan norma-norma (Antonio,2001:15).

Perkembangan perbankan syariah di berbagai negara di dorong oleh adanya kehendak sebagian masyarakat untuk melaksanakan kegiatan ekonomi yang sejalan dengan nilai dan prinsip syariah (kegiatan perbankan) bebas dari riba. Selain itu perbankan syariah secara sistem operasional maupun produk-produk yang dihasilkan mengutamakan pentingnya moralitas, keadilan dan transparansi dalam kegiatan operasionalnya (Karim,2004).

Peningkatan sektor keuangan syariah di Indonesia saat ini semakin berkembang. Hal tersebut dibuktikan dengan semakin berkembanganya lembaga keuangan syariah yang salah satunya yaitu bank syariah. Bank adalah badan usaha yang menghimpun dana dari masyarakat dalam bentuk simpanan dan menyalurkannya kepada masyarakat dalam bentuk kredit maupun dalam bentuk lain yang tujuannnya untuk meningkatkan kesejahteraan rakyat. Dalam kegiatan penghimpunan dana dari masyarakat dalam bentuk simpanan

1) Jurnal ini merupakan bagian dari skripsi Rosi Astrika Agustina, NIM : 041211431152 , yang diuji pada 16 Februari 2017 
Agustina, et al/ Jurnal Ekonomi Syariah Teori dan Terapan Vol. 5 No. 3 Maret 2018: 216-230;

FAKTOR-FAKTOR YANG MEMPENGARUHI JUMLAH DEPOSITO MUDHARABAH BANK SYARIAH DI INDONESIA (PERIODE TAHUN 2013-2016)

tabungan, giro dan deposito. Sedangkan dalam kegiatan penyaluran dana berupa pinjaman atau pembiayaan kepada masyarakat. Pada grafik 1 terdapat data mengenai perkembangan lembaga keuangan perbankan syariah di Indonesia.

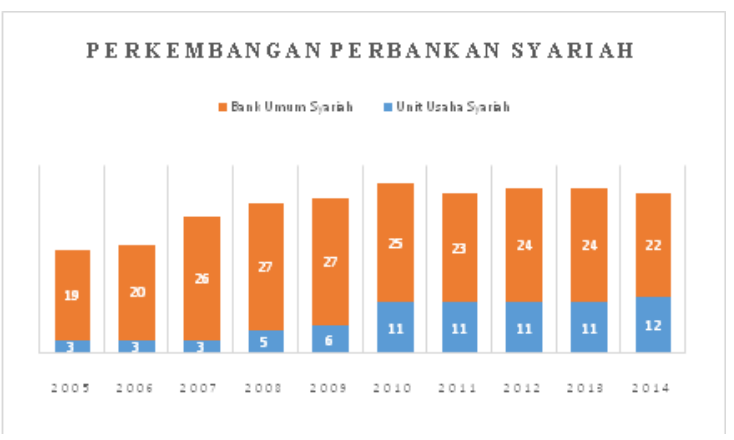

Sumber : Outlook Keuangan Syariah 2015

\section{Grafik 1}

Perkembangan Lembaga Kevangan Perbankan

Dari grafik 1 dapat diketahui perkembangan bank syariah di Indonesia dapat di gambarkan dengan pertumbuhan jumlah BUS maupun UUS. Pada tahun 2005 hanya terdapat 3 BUS yaitu Bank Muamalat, Bank Syariah Mandiri dan Bank Mega Syariah. Jika dilihat pertumbuhan perbankan syariah dari tahun ke tahun pertumbuhan UUS jauh lebih tinggi dibandingkan dengan BUS, namun pada tahun 2010 terjadi penurunan jumlah UUS dikarenakan ada beberapa UUS yang melakUkan Spin Off. Penambahan BUS terbesar terjadi pada tahun 2010 (5 BUS baru). Tahun 2013 ada pengurangan jumlah UUS dikarenakan tutupnya HSBC Syariah dan pada pertengahan 2014 juga kembali terjadi pengurangan dari jumlah UUS
dikarenakan BTPN Syariah yang
melakukan spin off di bulan Juli 2014.

Di Indonesia perkembangan perbankan syariah dimulai dengan munculnya UU No. 7 Tahun 1992 yang saat ini telah diperbaiki dengan UU No. 10 Tahun 1998. Keberadaan undang-undang tersebut memberikan peluang bagi perbankan di Indonesia dalam melakukan kegiatan perbankan berdasarkan pada syariah Islam. Dalam undang-undang tersebut diatur dengan rinci landasan hukum serta jenis-jenis usaha yang dapat dioperasikan dan diimplementasikan oleh bank syariah. Undang-undang tersebut juga memberikan arahan bagi bank konvensional untuk membuka cabang syariah atau mengkorversi diri secara total menjadi bank syariah ( Antonio, 2001: 26). Pada tabel 1 terdapat data mengenai perkembangan kantor dan jumlah bank umum syariah di Indonesia.

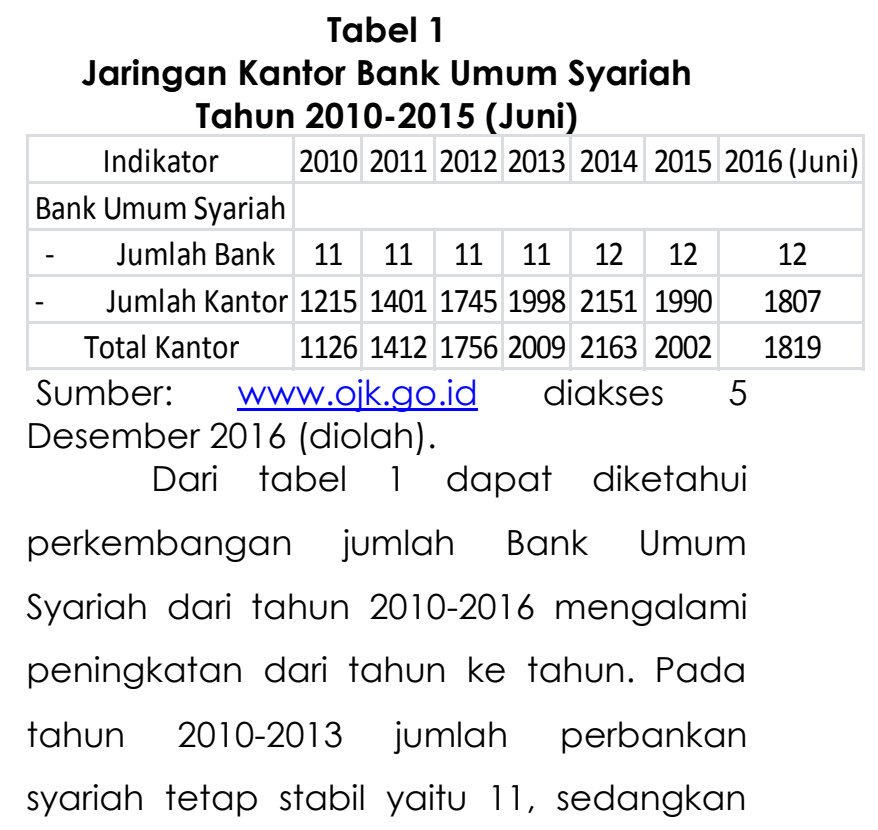


Agustina, et al/ Jurnal Ekonomi Syariah Teori dan Terapan Vol. 5 No. 3 Maret 2018: 216-230;

FAKTOR-FAKTOR YANG MEMPENGARUHI JUMLAH DEPOSITO MUDHARABAH BANK SYARIAH DI INDONESIA (PERIODE TAHUN 2013-2016)

jumlah kantor dari tahun 2010-2014 terus meningkat dibandingkan tahun 2015-2016 mengalami penurunan. Pada tahun 20142016 jumlah bank syariah mengalami peningkatan yaitu 12 bank, namun jumlah kantor bank syariah menurun pada tahun 2015 menjadi 1990 dan di tahun 2016 menjadi 1819. Berdasarkan tabel 1.1 menunjukkan perkembangan perbankan syariah di Indonesia cukup baik dengan bertambahnya jumlah bank yang meningkat, sedangkan jumlah kantor mengalami penurunan.

Menurut UU RI No.7 Tahun 1992 Bab I pasal 1 ayat, "Bank adalah badan usaha yang menghimpun dana dari masyarakat dalam bentuk simpanan, dan menyalurkannya kepada masyarakat dalam rangka meningkatkan taraf hidup rakyat banyak". Peranan perbankan dalam mengembangkan suatu bisnis usaha sangat penting karena selain berperan sebagai perantara antara pengembangan pihak yang kelebihan dana dengan pihak yang kekurangan dana, perbankan juga mampu mempengaruhi siklus usaha dalam perekonomian secara keseluruhan, sehingga perbankan mempengaruhi sirklus usaha dalam perekonomian secara keseluruhan, sehingga perbankan mempunyai tujuan untuk dapat memberikan manfaat yang besar bagi masyarakat.

Menurut Rivai dan Arifin (2010) usaha bank dalam dalam menghimpun dana dipengaruhi oleh faktor yang datang dari luar bank (eksternal) dan faktor yang bersumber dari bank itu sendiri (internal). Faktor eksternal yang mempengaruhi penghimpunan dana perbankan antara lain kondisi perekonomian, kegiatan dan kondisi pemerintah, kondisi atau perkembangan pasar vang dan pasar modal. Sedangkan faktor internal antara lain produk bank, kebijakan bagi hasil, kualitas layanan, suasana kantor bank, lokasi kantor dan reputasi bank. Selain faktor tersebut, keamanan atas dana yang dititipkan atau diinvestasikan merupakan faktor yang dipertimbangkan (Ismail,2011).

Salah satu bentuk investasi yang cukup diminati oleh masyarakat adalah deposito. Deposito adalah simpanan yang penarikannya hanya dapat dilakukan pada waktu-waktu tertentu menurut perjanjian antara penyimpan dengan bank yang bersangkutan. Deposito mudharabah adalah dana yang disimpan di bank dimana pengambilannya berdasarkan jangka waktu yang telah ditentukan, bagi hasil keuntungan sesuai dengan nisbah atau prosentase yang telah disepakati bersama. Dalam deposito syariah periodenya sama dengan bank konvensional, yaitu berjangka waktu 1 bulan, 3bulan, dan 12 bulan. 
Agustina, et al/ Jurnal Ekonomi Syariah Teori dan Terapan Vol. 5 No. 3 Maret 2018: 216-230;

FAKTOR-FAKTOR YANG MEMPENGARUHI JUMLAH DEPOSITO MUDHARABAH BANK SYARIAH DI INDONESIA (PERIODE TAHUN 2013-2016)

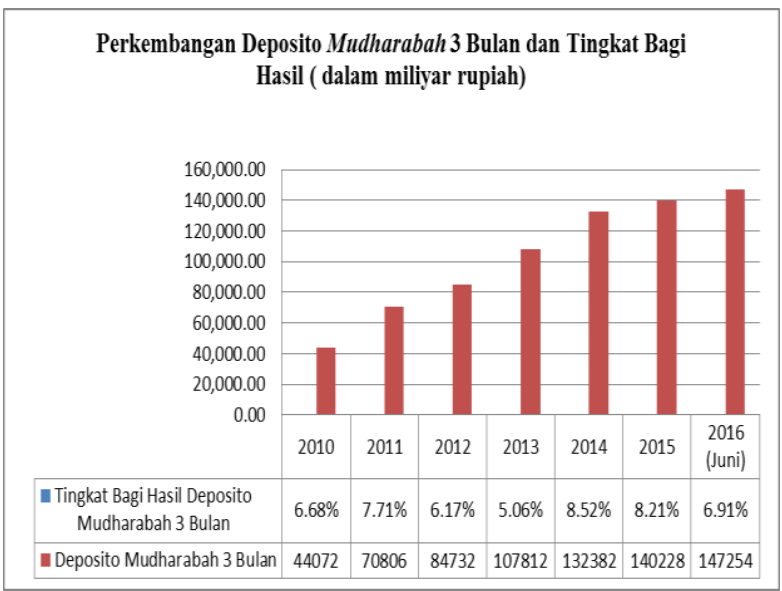

Sumber : Statistik Perbankan Syariah 2016

\section{Grafik 2}

Perkembangan Deposito Mudharabah dan Tingkat Bagi Hasil

Dari grafik 2 dapat diketahui perkembangan deposito mudharabah dan tingkat bagi hasil deposito mudharabah 3 bulan. Berdasarkan data statistik perbankan syariah pada tahun 2010-2016 jumlah deposito mudharabah yang dihimpun oleh perbankan syariah mengalami peningkatan dari Rp 44.072 miliar menjadi Rp 147.254 miliar. Dalam rentang waktu enam tahun jumlah deposito mudharabah naik sebesar $141,25 \%$. Berdasarkan data statistik perbankan syariah pada tahun 2010-2016 tingkat bagi hasil deposito mudharabah mengalami peningkatan dari $6.68 \%$ pada tahun 2010 menjadi $8.10 \%$ pada tahun 2016. Hal tersebut menunjukkan bahwa deposito mudharabah 3 bulan dan tingkat bagi hasil pada setiap tahunnya mengalami perkembangan yang baik, oleh karena itu deposito mudharabah cukup di minati oleh nasabah. Pada dasarnya nasabah dalam menempatkan dananya di bank syariah tentunya dipengaruhi oleh motif untuk mendapatkan keuntungan, sehingga tingkat bagi hasil yang diberikan bank syariah semakin tinggi maka alokasi dana investasi yang di investasikan di bank syariah akan semakin besar.

Faktor eksternal yang dapat mempengaruhi jumlah deposito mudharabah salah satunya adalah inflasi. Inflasi atau kenaikan harga-harga yang tinggi dan terus-menerus akan menimbulkan beberapa dampak buruk kepada individu dan masyarakat, penabung, kreditor atau debitor dan produsen, selain itu juga pada kegiatan perekonomian secara keseluruhan. Dampak inflasi bagi para penabung menyebabkan orang enggan untuk menabung karena nilai mata vang semakin menurun. Bila seseorang enggan untuk menabung, maka dunia usaha dan investasi akan sulit berkembang, karena berkembanganya dunia usaha membutuhkan dana dari masyarakat yang di simpan di bank (Huda,et al., 2009).

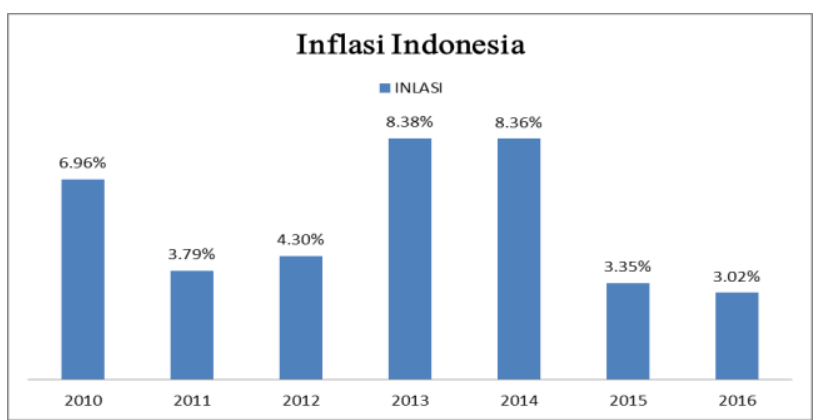

Sumber : Bank Indonesia

Grafik 3

Inflasi Indonesia Tahun 2010-2016 
Agustina, et al/ Jurnal Ekonomi Syariah Teori dan Terapan Vol. 5 No. 3 Maret 2018: 216-230;

FAKTOR-FAKTOR YANG MEMPENGARUHI JUMLAH DEPOSITO MUDHARABAH BANK SYARIAH DI INDONESIA (PERIODE TAHUN 2013-2016)

Berdasarkan grafik 1.3, dapat diketahui tingkat inflasi yang terjadi di Indonesia pada tahun 2010 sampai 2016. Pada tahun 2010 tingkat inflasi sebesar 6,96\%, tahun 2011 turun menjadi 3,79\%, tahun 2012 kembali naik menjadi 4,3\%, tahun 2013 terjadi kenaikan inflasi yang cukup tinggi sebesar 8,38\%, tahun 2014 inflasi turun menjadi 8.36\%,tahun 2015 tingkat inflasi turun menjadi $3,35 \%$, dan pada tahun 2016 tingkat inflasi rurun menjadi $3,02 \%$. Berdasarkan grafik 1.3 menunjukkan tingkat inflasi Indonesia yang tidak stabil dengan kenaikan dan penurunan pada setiap tahunnya.

Inflasi merupakan kecenderungan dari harga-harga untuk naik secara umum dan terus-menerus selama periode tertentu. Apabila tingkat inflasi mengalami kenaikan maka deposito perbankan syariah akan mengalami penurunan. Hal ini di sebabkan ketika inflasi mengalami kenaikan, maka para nasabah akan mencairkan dananya untuk mempertahankan tingkat konsumsinya.

Faktor internal yang berpengaruh terhadap pendanaan perbankan khususnya perbankan syariah yaitu bagi hasil yang diterima nasabah. Tinggi rendahnya bagi hasil yang ditawarkan bank kepada nasabah untuk menyimpan dananya pada bank tersebut (Rivai dan Arifin,2010).

Menurut Agustiano (2005:56) bagi hasil adalah keuntungan atau hasil yang diperoleh dari pengelolaan dana baik investasi maupun transaksi jual beli yang diberikan nasabah. Pengertian mudharabah adalah perjanjian atau suatu jenis kerjasama, dimana pihak pertama (sharibul maal) menyediakan dana dan pihak kedua (mudharib) bertanggungjawab atas pengelolaan dana usaha (Wiroso, 2005:56). Maka tingkat bagi hasil jika dihubungkan dengan jumlah deposito mudharabah maka bagi hasil deposito tersebut akan menunjukkan hasil dalam pertumbuhan atau perkembangan jumlah deposito mudharabah yang diinvestasikan oleh nasabah.

Selain itu, faktor internal yang berpengaruh terhadap perbankan syariah adalah ukuran perusahaan (bank). Pada umumnya nasabah yang menginvestasikan dananya di bank dengan motif untuk memperoleh keuntungan. Ukuran perusahaan (bank) merupakan ukuran atau besarnya aset yang dimiliki perusahaan ukuran bank memiliki kecenderungan kuat untuk mengahasilkan profit yang tinggi. Semakin besar ukuran bank, maka masyarakat akan cenderung menyimpan uangnya di bank tersebut karena masyarakat berpikir akan merasa aman menyimpan dananya di sana (Nur Anisa,dkk ,2013)

Perusahaan dengan ukuran yang lebih besar memiliki akses yang lebih besar untuk mendapat sumber pendanaan dari sumber, sehingga perusahaan dengan ukuran besar memiliki probabilitas lebih 
Agustina, et al/ Jurnal Ekonomi Syariah Teori dan Terapan Vol. 5 No. 3 Maret 2018: 216-230;

FAKTOR-FAKTOR YANG MEMPENGARUHI JUMLAH DEPOSITO MUDHARABAH BANK SYARIAH DI INDONESIA (PERIODE TAHUN 2013-2016)

besar untuk memenangkan persaingan atau bertahan dalam industri pada sisi lain, perusahaan yang kecil lebih fleksibel dalam menghadapi ketidakpastian, karena perusahaan kecil lebih cepat bereaksi terhadap perusahaan yang mendadak.

Dalam penelitian sebelumnya yang dilakukan di Malaysia (Haron dan Ahmad, 2000), tingkat suku bunga konvensional akan mempunyai hubungan negatif terhadap dana deposito bank syariah, sedangkan tingkat bagi hasil akan mempunyai hubungan positif terhadap jumlah dana deposito bank syariah. Dari penjelasan tersebut, maka dasar asumsi bahwa para deposan menyimpan vangnya di dana deposito berjangka bank konvensional dengan motif maximization. Jika manajemen bank syariah juga mempunyai asumsi yang sama, maka mereka akan berusaha untuk memberikan tingkat bagi hasil minimal sama atau bahkan lebih tinggi daripada yang diinfokan oleh bank konvensional.

Berdasarkan uraian diatas, bahwa tingkat bagi hasil dan ukuran perusahaan (bank) posisinya sangat penting dalam lembaga perbankan dan harus dikelola secara optimal, karena dana bank yang optimal akan memberikan ruang gerak yang cukup bagi pihak perbankan baik dalam aspek pembiayaan maupun likuiditasnya. Selain itu adanya kenaikan inflasi akan berdampak pada konsumsi yang nantinya akan berpengaruh pada minat investasi masyarakat tentunya pada deposito. Terkait dengan kemampuan perbankan syariah dalam menghimpun dana pihak ketiga, khususnya dana deposito mudharabah.

Berdasarkan latarbelakang yang telah dikemukakan, maka penulis akan meneliti dan menganalisis mengenai deposito mudharabah dengan melihat pengaruh inflasi,tingkat bagi hasil dan ukuran perusahaan secara imultan dan parsial terhadap jumlah deposito mudharabah bank syariah di Indonedia periode tahun 2013-2016?

\section{TINJAUAN PUSTAKA}

Deposito adalah bentuk simpanan yang mempunyai jumlah minimal tertentu, jangka waktu tertentu dan hasilnya lebih tinggi dari pada tabungan. Nasabah membuka membuka deposito dengan jumlah minimal tertentu dengan jangka waktu yang telah ditentukan dengan jangka waktu yang telah disepakati, sehingga nasabah tidak dapat mencairkan dananya sebelum jatuh tempo. Produk penghimpunan dana biasanya dipilih oleh nasabah yang memiliki kelebihan dana, sehingga selain bertujuan menyimpan dananya, bertujuan pula sebagai sarana berinvestasi (Nurianto,2010:35).

Deposito mudharabah adalah bentuk simpanan oleh nasabah kepada bank yang penarikannya hanya bisa dilakukan pada jangka waktu yang telah di tentukan dalam penyajian, jenis 
Agustina, et al/ Jurnal Ekonomi Syariah Teori dan Terapan Vol. 5 No. 3 Maret 2018: 216-230;

FAKTOR-FAKTOR YANG MEMPENGARUHI JUMLAH DEPOSITO MUDHARABAH BANK SYARIAH DI INDONESIA (PERIODE TAHUN 2013-2016)

penyimpanan. Pada penyimpanan dana diberikan hak untuk memperoleh laba bank sesuai dengan prosentase yang dijanjikan, yang dihitung sesuai dengan peranan dana dalam pembentukan bank.

Inflasi adalah suatu proses meningkatnya harga-harga secara umum terus-menerus (continue) berkaitan dengan mekanisme pasar yang dapat disebabkan oleh berbagai faktor, antara lain konsumsi masyarakat yang meningkat, kenaikan likuiditas di pasar yang memicu konsumsi atau bahkan spekulasi. Dengan kata lain, inflasi merupakan proses menurunnya nilai mata vang secara terus-menerus (Mankiw.2005:164).

Menurut Karim (2007:175),"bagi hasil adalah bentuk return dari kontrak investasi". Sistem bagi hasil yang diterapkan dalam ekonomi Islam merupakan cerminan dari perkembangan dan pertumbuhan perekonomian.

(Muhammad,2004:19) menyatakan

bahwa Sistem bagi hasil adalah system pembagian hasil baik berupa keuntungan (profit) maupun pendapatan (revenue) berdasarkan nisbah yang telah disepakati di awal akad, dari kerjasama minimal dua belah pihak, yaitu satu pihak berperan sebagai penyandang dana (shahibul maal) dan pihak lainnya menjadi pekerja (mudharib). Pada intinya mekanisme investasi bagi hasil pada dasarnya adalah "kerjasama yang baik antara shahibul maal dengan mudharib".

Tingkat bagi hasil deposito pada bank syariah merupakan salah satu faktor yang mempengaruhi seseorang untuk mendepositokan hartanya, pada tingkat bagi hasil deposito tinggi, maka masyarakat akan lebih cenderung mendepositokan uangnya dari pada digunakan untuk dikonsumsi. Salah satu tujuan nasabah mendepositokan vangnya adalah untuk memperoleh keuntungan yang sesuai dengan harapan, maka besar kemungkinan jika tingkat bagi hasil deposito bank syariah mengalami penurunan, maka para deposan tidak akan melanjutkan menggunakan jasa deposito bank syariah. Hal tersebut terjadi karena tidak semua nasabah bank syariah merupakan nasabah yang memilih menggunakan jasa perbankan syariah disebabkan faktor keyakinan.

Ukuran perusahaan adalah suatu skala dimana besar kecilnya perusahaan dapat diklasifikasikan menurut berbagai cara, antara lain dengan total aktiva, long size, nilai pasar saham, dan lain-lain. Pada dasarnya ukuran perusahaan terbagi menjadi 3 kategori yaitu perusahaan besar (large firm), perusahaan menengah (medium size) dan perusahaan kecil (small firm). Ukuran perusahaan yang digunakan 
Agustina, et al/ Jurnal Ekonomi Syariah Teori dan Terapan Vol. 5 No. 3 Maret 2018: 216-230;

FAKTOR-FAKTOR YANG MEMPENGARUHI JUMLAH DEPOSITO MUDHARABAH BANK SYARIAH DI INDONESIA (PERIODE TAHUN 2013-2016)

dalam penelitian ini adalah total aktiva atau total asset (Nur Anisa,dkk, 2013).

Investor mempertimbangkan umur perusahaan dalam mengambil keputusan untuk berinvestasi. Hal tersebut di karenakan mereka beranggapan bahwa perusahaan yang telah berdiri lama biasanya memiliki resiko yang lebih sedikit. Semakin lama perusahaan berdiri tentunya lebih berpengalaman dalam mengelola usahanya, sehingga memungkinkan untuk menghasilkan laba juga besar, yang nantinya akan menguntungkan investor. Kasmir (2013:238).

\section{Model Analisis}

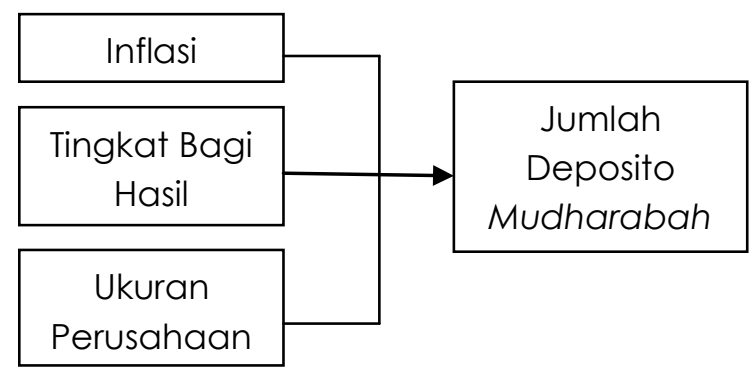

Sumber : Data diolah

Gambar 2.1

Pengaruh Inflasi, Tingkat Bagi Hasil dan Ukuran Perusahaan Terhadap Jumlah Deposito Mudharabah

\section{METODOLOGI PENELITIAN}

\section{Pendekatan Penelitian}

Penelitian ini meunggunakan pendekatan metode kuantitatif. Metode ini disebut metode kuantitatif karena data penelitian berupa angka-angka dan analisisnya menggunakan statistik (Sugiyono,2009:12).

\section{Identifikasi Variabel}

Variabel Independen dalam penelitian ini adalah inflasi (X1), tingkat bagi hasil (X2), dan ukuran perusahaan (X3) serta variabel dependen adalah jumlah deposito mudharabah (Y).

\section{Definisi Operasional}

1. Inflasi (X1)

$$
\text { Inflasi merupakan variabel }
$$
dependen, inflasi dalam penelitian ini adalah peningkatan dalam seluruh tingkat harga. Kenaikan harga tersebut berlangsung terus-menerus dan berkepanjangan. Inflasi merupakan kecenderungan dari harga-harga untuk naik secara umum dan terus menerus selama periode tertentu (Mankiw.2005:164). Budiono (2005:157) menyatakan bahwa tingkat inflasi (rate of inflation) yaitu tingkat perubahan dari tingkat harga secara umum.

2. Tingkat Bagi Hasil (X2)

Tingkat bagi hasil merupakan variabel dependen, tingkat bagi hasil dalam dalam penelitian ini adalah total perolehan bagi hasil untuk nasabah sebagai pemilik deposito mudharabah yang menginvestasikan dananya pada bank tersebut. Data tingkat bagi hasil yang digunakan dalam penelitian ini diperoleh dari Laporan Keuangan Bank Umum Syariah (BUS) triwulan mulai tahun 2013 sampai 2016.

3. Ukuran Perusahaan (X3)

Ukuran perusahaan merupakan variabel dependen, ukuran perusahaan 
Agustina, et al/ Jurnal Ekonomi Syariah Teori dan Terapan Vol. 5 No. 3 Maret 2018: 216-230;

FAKTOR-FAKTOR YANG MEMPENGARUHI JUMLAH DEPOSITO MUDHARABAH BANK SYARIAH DI INDONESIA (PERIODE TAHUN 2013-2016)

dalam penelitian ini adalah ukuran atau besarnya aset yang dimliki oleh perusahaan (bank). Variabel ukuran perusahaan diukur dengan rata-rata jumlah nilai total aset yang dimiliki suatu perusahaan (total aset) selama periode 2013 sampai 2016.

\section{Jenis dan Sumber Data}

Jenis data yang digunakan dalam penelitian ini adalah data panel. Data panel merupakan data sekunder. Data sekunder adalah data yang diperoleh dari sumber lain yang telah di olah oleh sumber tersebut atau bukan dari sumber utama. Data sekunder yang digunakan dalam penelitian ini diperoleh dari laporan keuangan Bank Umum Syariah (BUS) di Indonesia pada periode triwulan 1.2013 triwulan 3.2016 yang diinformasikan. Laporan kevangan yang digunakan dalam penelitian ini menyangkut salah satu data laporan keuangan bank seperti deposito mudharabah yang menggunakan data triwulan. Data lainnya yang diperlukan dalam penelititian ini adalah data triwulan seperti tingkat bagi hasil ,inflasi, ukuran perusahaan (total aset), dan deposito mudharabah periode triwulan 1.2013 - triwulan 3.2016. Laporan kevangan tersebut digunakan untuk menghitung jumlah deposito mudharabah pada bank syariah di Indonesia.

\section{Populasi dan Sampel}

Populasi dalam penelitian ini adalah Bank Umum Syariah yaitu bank devisa yang ada di Indonesia yang memenuhi dalam kriteria penelitian. Menurut data statistik perbankan syariah pada Bulan Juni 2016, jumlah bank umum syariah di Indonesia terdapat 12 bank umum syariah. Teknik pengambilan sampel yang digunakan dalam penelitian ini adalah purposive sampling yang merupakan teknik pengambilan sampel dengan pertimbangan atau kriteria tertentu.

Bank Umum Syariah (BUS) yang menjadi sampel dan digunakan dalam penelitian ini dengan menggunakan kriteria sampel sebagai berikut :

1. Bank umum syariah yaitu bank devisa yang terdaftar di Bank Indonesia periode triwulan 1.2013 triwulan 3.2016 .

2. Menyajikan laporan keuangan triwulan yang dipublikasikan dalam periode triwulan 1.2013 - triwulan 3.2016.

3. Memiliki data lengkap terkait tingkat bagi hasil dan aset.

4. Bank Umum Syariah (BUS) tidak menderita rugi besar dan neracanya tidak menunjukkan kekayaan negatif.

Sampel yang di dapat selama periode triwulan 1. 2013 - triwulan 3.2016 berdasarkan kriteria diatas terdapat 6 Bank Umum Syariah yang termasuk dalam bank devisa di Indonesia diantaranya adalah : (1) Bank Syariah Mandiri, (2) Bank Muamalat Indonesia, (3) Bank BNI Syariah, 
Agustina, et al/ Jurnal Ekonomi Syariah Teori dan Terapan Vol. 5 No. 3 Maret 2018: 216-230;

FAKTOR-FAKTOR YANG MEMPENGARUHI JUMLAH DEPOSITO MUDHARABAH BANK SYARIAH DI INDONESIA (PERIODE TAHUN 2013-2016)

(4) Bank Mega Syariah, (5) Bank Rakyat Indonesia Syariah, (6) Bank Panin Syariah.

\section{Teknik Analisis}

Penelitian ini merupakan penelitian kuantitatif. Teknik analisis yang digunakan dalam penelitian ini adalah regresi data panel. Proses perhitungan dalam penelitian ini menggunakan progam Eviews. Teknik analisis data dalam penelitian ini memanfaatkan data yang didapatkan dari penggabungan antara data cross section (beberapa BUS tertentu) dengan data time series (lingkup waktu selama beberapa tahun tertentu) atau disebut dengan data panel. Langkah pertama dalam teknik analisis ini adalah uji asumsi klasik yaitu uji normalitas, uji heterokedasitas dan uji linieritas. Setelah uji asumsi terpenuhi, dilanjutkan uji chow untuk menentukan model PLS atau FEM yang digunakan. Apabila FEM diterima selanjutnya melakukan uji hausman untuk menentukan model PLS atau FEM yang digunakan. Apabila FEM diterima, selanjutnya melakukan uji hausman untuk menentukan model FEM atau REM yang tepat digunakan. Setelah menentukan model yang tepat, uji berikutnya adalah uji $\dagger$ dan uji $F$, lalu koefisien determinasi. Uji $\dagger$ digunakan untuk menguji pengaruh secara parsial variabel independen terhadap variabel dependen, sedangkan uji $t$ digunakan untuk menguji pengaruh secara simultan variabel independen terhadap variabel dependen.

\section{HASIL DAN PEMBAHASAN}

Data yang digunakan lolos uji asumsi klasik. Langkah berikutnya uji chow untuk menentukan model PLS atau FEM yang tepat digunakan.

Tabel 2

Hasil Uji F (Chow Test)

\begin{tabular}{|c|c|c|}
\hline Effects Test & Statistic & d.f. Prob. \\
\hline \multirow[t]{2}{*}{ Cross-section F } & 50,834454 & $(5 ; 81) 0,0000$ \\
\hline & 127,81759 & \\
\hline Cross-section Chi-square & 4 & 50,0000 \\
\hline
\end{tabular}

Sumber : Output Eviews 7

Berdasarkan tabel 2 diperoleh Pvalue (Cross-section F) sebesar 0,0000 lebih kecil dari a $(0,05)$ sehingga $\mathrm{H}_{0}$ ditolak dan $\mathrm{H}_{1}$ diterima, dapat disimpulkan bahwa model sementara yang terbaik untuk digunakan yaitu model Fixed Effect (FEM). Selanjutnya dilakukan Uji Hausman untuk mengetahui apakah teknik regresi data panel dengan fixed effect lebih dari model regresi data panel random effect. Hipotesis Uji Hausman adalah :

$\mathrm{H}_{0}$ : Common Effect

$\mathrm{H}_{1}$ : Fixed Effect

Tabel 3

Hasil Pengujian Hausman Test

\begin{tabular}{|lrr|}
\hline Test Summary & Chi-Sq. Statistic & Chi-Sq. d.f. Prob. \\
\hline $\begin{array}{l}\text { Cross-section } \\
\text { random }\end{array}$ & 0,000000 & 31,0000 \\
\hline
\end{tabular}

Sumber : Output Eviews 7

Berdasarkan tabel 3 diperoleh Pvalue Cross-section random sebesar 1,0000 yang berarti lebih besar dari a $(0,05)$ sehingga $\mathrm{H}_{0}$ diterima dan $\mathrm{H}_{1}$ ditolak, 
Agustina, et al/ Jurnal Ekonomi Syariah Teori dan Terapan Vol. 5 No. 3 Maret 2018: 216-230;

FAKTOR-FAKTOR YANG MEMPENGARUHI JUMLAH DEPOSITO MUDHARABAH BANK SYARIAH DI INDONESIA (PERIODE TAHUN 2013-2016)

dapat disimpulkan bahwa hasil pengujian tidak valid (Cross-section test variance is invalid. Hausman statistic set to zero) sehingga diperlukan acuan untuk menentukan model yang akan digunakan. Pemilihan model pendekatan menurut para ahli ekonometri (Nachrowi dan Usman, 2006) :

1. Apabila jumlah individu lebih besar dari jumlah koefisien termasuk intercept REM dapat digunakan.

2. Apabila dalam data panel, jumlah waktu lebih besar dari jumlah individu, FEM dapat digunakan.

3. Apabila dalam data panel, jumlah waktu lebih kecil dari jumlah individu, REM dapat digunakan.

Berdasarkan landasan diatas pada poin kedua yaitu jumlah waktu (t) sebanyak 15 triwulan lebih besar dari jumlah individu (N) sebanyak 6 bank, maka dapat disimpulkan bahwa Fixed Effect Model (FEM) merupakan model yang terbaik untuk digunakan. Selain itu dibandingkan model REM, model FEM memiliki beberapa keunggulan (Nachrowi dan Usman,2006) yaitu:

1. Membedakan efek individual dan efek waktu.

2. Tidak perlu mengasumsikan komponen error tidak berkorelasi dengan variabel bebas yang sulit dipenuhi.

Selanjutnya dilakukan uji $†$ (uji parsial) dan uji $F$ (uji simultan). Variabel tingkat bagi hasil tidak berpengaruh signifikan terhadap jumlah deposito mudharabah di Indonesia dengan hasil nilai $p$-value sebesar $0,0950>$ a sebesar 0,05 . Variabel inflasi berpengaruh positif dan signifikan terhadap jumlah deposito mudharabah di Indonesia dengan hasil nilai $p$-value 0,0038 < a sebesar 0,05. Variabel ukuran perusahaan berpengaruh positif dan signifikan terhadap jumlah deposito mudharabah bank syariah di Indonesia dengan nilai p-value 0,0000 < a sebesar 0,05. Hal tersebut dapat dilihat pada hasil uji † di bawah ini.

Tabel 4

Hasil Uji $t$

\begin{tabular}{|ccc|}
\hline Variable & t-Statistic & Prob. \\
\hline \hline X1? & 2,978633 & 0,0038 \\
X2? & 1,689598 & 0,0950 \\
X3? & 4,287494 & 0,0000 \\
C & 0,789937 & 0,4319 \\
\hline
\end{tabular}

Sumber : Output Eviews 7

Secara simultan, hasil uji $F$ yaitu $p$ value sebesar 0,0000 lebih kecil dari pada 0,05 (tingkat signifikansi 5\%). Jadi, variabel inflasi, tingkat bagi hasil dan ukuran perusahaan secara bersama-sama berpengaruh positif dan signifikan terhadap jumlah deposito mudharabah bank syariah di Indonesia periode tahun 2013-2016.

Berdasarkan hasil estimasi FEM dapat dilihat bahwa koefisien determinasi dari hasil regresi diatas yaitu 95,6145\%, sedangkan sisanya yaitu $4,3855 \%$ dijelaskan oleh variabel lain yang tidak termasuk dalam penelitian ini. 
Agustina, et al/ Jurnal Ekonomi Syariah Teori dan Terapan Vol. 5 No. 3 Maret 2018: 216-230;

FAKTOR-FAKTOR YANG MEMPENGARUHI JUMLAH DEPOSITO MUDHARABAH BANK SYARIAH DI INDONESIA (PERIODE TAHUN 2013-2016)

Pengaruh Inflasi Terhadap Jumlah

Deposito Mudharabah Bank Syariah di Indonesia

Hasil penelitian menunjukan bahwa variabel inflasi berpengaruh positif signifikan terhadap jumlah deposito mudharabah bank syariah di Indonesia periode tahun 2013-2016. Hal tersebut dapat dilihat dari signifikansi yang dihasilkan, yaitu sebesar 0,0038. Nilai signifikansi tersebut lebih kecil dari 0,05 sehingga $\mathrm{H}_{3}$ diterima. Dengan begitu, hasil penelitian ini menerima bahwa inflasi dapat mempengaruhi deposito mudharabah bank syariah. Selain itu, hasil penelitian ini mendukung hasil penelitian yang dilakukan oleh Ani dan Wasilah (2010) menyatakan bahwa inflasi berpengaruh signifikan terhadap deposito mudharabah.

Berdasarkan hasil penelitian, variabel inflasi menunjukkan hasil yang signifikan terhadap jumlah deposito mudharabah. Namun bila dilihat dari tingkat inflasi di Indonesia dari tahun 2013 hingga tahun 2016, menunjukkan bahwa dari tahun 2010-2016 inflasi yang tinggi terjadi pada tahun 2013-2014 dibandingkan tahun sebelumnya. Pada akhir tahun 2015 inflasi turun sebesar 5,01\% menjadi 3,35\% dan di tahun 2016 triwulan 3 naik sebesar $3,48 \%$ menjadi $6,83 \%$. Hal tersebut menunjukan bahwa inflasi memiliki pengaruh terhadap jumlah deposito mudharabah bank syariah, karena pada saat terjadi inflasi masyarakat mampu mempertahankan tingkat konsumsi dan melindunginya dari ketidakpastian yang akan terjadi dimasa depan sehingga nasabah akan meningkatkan jumlah simpanan (deposito mudharabah).

Pengaruh Tingkat Bagi Hasil Terhadap Jumlah Deposito Mudharabah Bank Syariah di Indonesia

Hasil penelitian menunjukan bahwa variabel tingkat bagi hasil tidak berpengaruh signifikan terhadap jumlah deposito mudharabah bank syariah di Indonesia periode tahun 2013-2016. Hal tersebut dapat dilihat dari signifikansi yang dihasilkan, yaitu sebesar 0,0950. Nilai signifikansi tersebut lebih besar dari 0,05 sehingga $\mathrm{H}_{2}$ ditolak. Dengan begitu, hasil penelitian ini menerima bahwa tingkat bagi hasil dapat mempengaruhi deposito mudharabah bank syariah. Selain itu, hasil penelitian ini mendukung hasil penelitian yang dilakukan oleh Fauzan (2016) yang juga menyatakan bahwa tingkat bagi hasil ridak berpengaruh signifikan terhadap deposito mudharabah.

Berdasarkan hasil penelitian tingkat bagi hasil pada bank umum syariah di Indonesia menunjukkan hasil yang tidak signifikan terhadap jumlah deposito mudharabah. Namun bila dilihat dilihat dari presentase tingkat bagi hasil deposito mudharabah 3 bulan dari tahun 2013-2016 pada bank umum syariah, tingkat bagi hasil deposito mudharabah 3 bulan pada tahun 2014-2016 terlihat lebih tinggi dari 
Agustina, et al/ Jurnal Ekonomi Syariah Teori dan Terapan Vol. 5 No. 3 Maret 2018: 216-230;

FAKTOR-FAKTOR YANG MEMPENGARUHI JUMLAH DEPOSITO MUDHARABAH BANK SYARIAH DI INDONESIA (PERIODE TAHUN 2013-2016)

tahun sebelumnya dan pada tahun 2016 lebih rendah. Hal tersebut menunjukkan bahwa faktor motivasi untuk mendapatkan return yang tinggi tidak menjadi dasar utama dalam memilih bank, namun lebih kepada kesesuaian dengan syariah. Selain itu, membuktikan bahwa tingkat bagi hasil tidak berpengaruh terhadap jumlah deposito mudharabah bank syariah, karena faktor agama merupakan faktor utama yang menjadi alasan nasabah menyimpan dananya di bank syariah. Karakter nasabah bank syariah merupakan emosional yang non profit oriented.

Pengaruh Ukuran Perusahaan Terhadap Jumlah Deposito Mudharabah Bank

\section{Syariah di Indonesia}

Hasil penelitian menunjukan bahwa variabel ukuran perusahaan berpengaruh positif signifikan terhadap jumlah deposito mudharabah bank syariah di Indonesia periode tahun 20132016. Hal tersebut dapat dilihat dari signifikansi yang dihasilkan, yaitu sebesar 0,0000 . Nilai signifikansi tersebut lebih kecil dari 0,05 sehingga $\mathrm{H}_{4}$ diterima. Dengan begitu, hasil penelitian ini menerima bahwa ukuran perusahaan dapat mempengaruhi jumlah deposito mudharabah bank syariah. Selain itu, hasil penelitian ini mendukung hasil penelitian yang dilakukan oleh Ani dan Wasilah (2010) yang juga menyatakan bahwa ukuran perusahaan (ukuran bank) berpengaruh positif dan signifikan terhadap deposito mudharabah.

Berdasarkan hasil penelitian, variabel ukuran perusahaan menunjukkan hasil yang signifikan terhadap jumlah deposito mudharabah. Namun bila dilihat dari jumlah total asset ukuran perusahaan dari tahun 2013 hingga tahun 2016 pada bank umum syariah di Indonesia, bank dengan tolat asset tertinggi adalah Bank Syariah Mandiri, sedangkan bank dengan total asset terendah adalah Bank Panin Syariah. Hal tersebut menunjukan bahwa bank dengan ukuran perusahaan yang dilihat dari total asset yang besar lebih diminati oleh nasabah atau masyarakat, karena dirasa aman jika berinvestasi pada bank dengan ukuran perusahaan yang besar.

\section{SIMPULAN DAN SARAN}

\section{SIMPULAN}

Berdasarkan pembahasan hasil penelitian dan juga pembahasan yang telah dilakukan mengenai pengaruh Inflasi, Tingkat Bagi Hasil dan Ukuran Perusahaan terhadap Jumlah Deposito Mudharabah Bank Syariah di Indonesia, maka simpulan yang dapat diambil adalah :

1. Variabel inflasi, tingkat bagi hasil dan ukuran perusahaan secara simultan berpengaruh signifikan terhadap jumlah deposito mudharabah bank syariah di Indonesia periode tahun 2013-2016 
pada signifikansi a $5 \%$ dengan probabilitas 0,00000 .

2. Variabel inflasi berpengaruh positif dan signifikan terhadap jumlah deposito mudharabah bank syariah di Indonesia periode tahun 2013 - 2016 pada signifikansi a 5\% dengan nilai t-statistik sebesar 2,978633 dan nilai signifikansi 0,0038 .

3. Variabel tingkat bagi hasil tidak berpengaruh signifikan terhadap jumlah deposito mudharabah bank syariah di Indonesia periode tahun 2013 - 2016 pada signifikansi a $5 \%$ dengan nilai t-statistik sebesar 1,689598 dan nilai signifikansi 0,0950 .

4. Variabel ukuran perusahaan berpengaruh positif dan signifikan terhadap jumlah deposito mudharabah bank syariah di Indonesia periode tahun 2013 2016 pada signifikansi a 5\% dengan nilai t-statistik 4,287494 dan nilai signifikansi 0,0000.

\section{DAFTAR PUSTAKA}

Al-Qur'an dan Terjemahannya. Agustiano, 2005. Penentuan Bagi Hasil Deposito Mudharabah di Bank Syariah, Dalam www.iaeipusat.net.

Ajija,Shochrul R dkk.2011. Cara Cerdas Menguasai Eviews. Jakarta: Salemba Empat.
Andriyanti, Ani dan Wasilah. 2010. Faktor-faktor yang Mempengaruhi Jumlah Penghimpunan Dana Pihak Ketiga (Deposito Mudharabah 1 Bulan) Bank Muamalat Indonesia (BMI). Jurnal Simposium Nasional Akuntansi XIII Purwokerto, Universitas Jenderal Soedirman Purwokerto.

Antonio,Muhammad

Syafi'i.2001.Bank Syariah Dari Teori Ke Praktek.Jakarta : Gema Insani Pers.

2009.

Bank Syariah Dari Teori Ke Praktik. Jakarta : Gema Insani Pers.

Ascarya. 2006. Akad dan Produk Bank Syariah. Jakarta : Raja Grafindo. .2007. Akad dan Produk Bank Syariah.Jakarta : Raja Grafindo.

Badan Pusat Statistik, Statistik Inflasi Indonesia Tahun 2010-2016.

Bank Indonesia, Outlook Perbankan Syariah 2015 Statistik Perbankan Syariah 2016

Bungin, Burhan. 2005..Metode Penelitian Kuantitatif.Jakarta : Kencana.

Eugene F. Brigham dan Joel F. Houston. 2010. Dasar - Dasar Manajemen Kevangan.Jakarta : Salemba Empat. 
Agustina, et al/ Jurnal Ekonomi Syariah Teori dan Terapan Vol. 5 No. 3 Maret 2018: 216-230;

FAKTOR-FAKTOR YANG MEMPENGARUHI JUMLAH DEPOSITO MUDHARABAH BANK SYARIAH DI INDONESIA (PERIODE TAHUN 2013-2016)

Haron, Sudin dan Norafifah

Ahmad. 2000. The Effects of

Conventional Interest Rates and Rate of Profit on Funds Deposited with Islamic Banking System in Malaysia. Jurnal Internasional Journal of Islamic Financial Services Vol.1 104.

Husni, Azhari. 2009. Faktor-faktor yang Mmepengaruhi Penghimpunan Dana Pihak Ketiga pada Perbankan Syariah di Indonesia periode : Januari 2006 Desember 2007.

Huda,N.,Idris., Nasution,M.E., Wiliasih, R. 2009. Eekonomi Makro Islam : Pendekatan Teoritis. Edisi 1. Jakarta : Kencana Prenada Group. Indrianto,H dan B.Supomo.2002. Metodologi Penelitian Bisnis.Yogyakarta: BPFE UGM.

Karim, Adiwarman. 2004. Bank Islam Analisis Fiqih dan Kevangan. Jakarta : PT. Grafindo Persada 2007. Ekonomi Makro Islam. Jakarta : PT. Grafindo Persada.

Kasmir.2013. Analisis Laporan Kevangan. Jakarta : Rajawali Pers. Menkiw. Georgy.2005. Pengantar Teori Makro. Jakarta : Erlangga.

Nachrowi, Djalal Nachrowi, Hardius Usman. 2006. Pendekatan Populer dan Praktis Ekonometrika untuk Analisis Ekonomi dan Keuangan.
Jakarta: Lembaga Penerbit Universitas Indonesia.

Nur Anisa, Ahmad dan Lailatul. 2013. Faktor - Faktor Yang Mempengaruhi Pertumbuhan Deposito Mudharabah Bank Syariah. Jurnal IImu dan Riset Akuntansi. Sekolah Tinggi IImu Ekonomi Indonesia (STESIA). Surabaya.

Rivai, Veithzal.dkk. 2007. Bank and Financial Institution Management Conventional And Sharia System. $1^{\text {st }}$ edition,. Jakarta : PT Raja Grafindo Persada.

Sudarsono, Heri. 2007. Bank dan Lembaga Kevangan Syariah (deskripsi dan ilustrasi). Yogyakarta : Ekonisia.

Sugiyono. 2009. Metode Penelitian Bisnis. Bandung : Alfabeta.

Yaya, Rizal, dkk.2009. Akuntansi Perbankan Syariah. Jakarta : Salemba Empat. http://www.bi.go.id http://www.ojk.go.id 